DOI https://doi.org/10.30525/978-9934-26-040-7-51

\title{
ДЕКЛАРУВАННЯ НЕДОСТОВІРНОЇ ІНФОРМАЦІЇ: ЗАКОНОДАВЧІ НОВЕЛИ
}

\author{
Красій М. О. \\ кандидатка юридичних наук, \\ дочентка кафедри публічного управління та адміністрування \\ Івано-Франківського національного технічного університету \\ нафти і газу \\ м. Івано-Франківськ, Україна
}

27 жовтня 2020 року Конституційний Суд України ухвалив рішення, проблематика якого тісно пов'язана із питанням криміналізації та декриміналізації суспільно небезпечного діяння. Це рішення стосовно неконституційності статті 366-1 Кримінального кодексу України (далі - КК України).

Відповідно до статті 147 Конституції України, Конституційний Суд України вирішує питання про відповідність Конституції України законів України та у передбачених цією Конституцією випадках інших актів, здійснює офіційне тлумачення Конституції України, а також інші повноваження відповідно до Основного Закону України [1].

Суддя Конституційного Суду України О.О. Первомайський вважає що, ст. 366-1 КК України сформульована з порушенням вимог юридичної визначеності та передбачуваності закону, що не відповідає принципу верховенства права, передбаченого ч. 1 ст. 8 Конституції України. Окрім того, на думку Конституційного Суду України, склад злочину, встановлений ст. 366-1 КК України, є надмірним покаранням за відповідні дії або бездіяльність осіб, уповноважених на виконання функцій держави або місцевого самоврядування. Тобто цей юридичний засіб протидії корупції не $\epsilon$ домірним (пропорційним) для досягнення визначеної законом легітимної мети щодо застосування кримінальноправової превенції у сфері обов'язкового декларування осіб, уповноважених на виконання функцій держави або місцевого самоврядування. Згідно з Рішенням Конституційного Суду України у справі за конституційним поданням 47 народних депутатів України щодо відповідності Конституції України (конституційності) окремих положень Закону України «Про запобігання корупції», КК України [2] така мета може бути досягнута іншими юридичними засобами, а саме шляхом 
дисциплінарної та (або) адміністративної відповідальності цих осіб [3]. Важко погодитися з такою думкою, оскільки без кримінально-правових заходів такої мети буде досягнути складно.

Однак, 4 грудня 2020 року Верховна Рада України відновила покарання за недостовірне декларування прийнявши Закон України «Про внесення змін до деяких законодавчих актів України щодо встановлення відповідальності за декларування недостовірної інформації та неподання суб'єктом декларування декларації особи, уповноваженої на виконання функцій держави або місцевого самоврядування» [4], яким доповнила КК України ст. 366-2 «Декларування недостовірної інформації», ст. 366-3 «Неподання суб'єктом декларування декларації особи, уповноваженої на виконання функцій держави або місцевого самоврядування» [5] та внесла зміни до ст. 172-6 Кодексу України про адміністративні правопорушення (далі - КУпАП) «Порушення вимог фінансового контролю» [6].

КУпАП передбачив, що подання завідомо недостовірних відомостей у декларації особи, уповноваженої на виконання функцій держави або місцевого самоврядування, - тягне за собою накладення штрафу від однієї тисячі до двох тисяч п'ятисот неоподатковуваних мінімумів доходів громадян. Відповідно до норм ст. 172-6 КУпАП за подання завідомо недостовірних відомостей у декларації особи, уповноваженої на виконання функцій держави або місцевого самоврядування, стосовно майна або іншого об'єкта декларування, що має вартість, настає у випадку, якщо такі відомості відрізняються від достовірних на суму від 100 до 500 прожиткових мінімумів для працездатних осіб [6].

У диспозиції ст. 366-2 КК України законодавець наголос робить на «умисному» внесенні суб' єктом декларування завідомо недостовірних відомостей до декларації особи, уповноваженої на виконання функцій держави або місцевого самоврядування, якщо такі відомості відрізняються від достовірних на суму від 500 до 4000 прожиткових мінімумів для працездатних осіб, або понад 4000 прожиткових мінімумів для працездатних осіб. А у санкції цієї статті зазначено, що такі діяння карається штрафом від двох тисяч п'ятисот до трьох тисяч неоподатковуваних мінімумів доходів громадян або громадськими роботами на строк від ста п'ятдесяти до двохсот сорока годин, 3 позбавленням права обіймати певні посади чи займатися певною діяльністю на строк до трьох років, або штрафом від трьох тисяч до п’яти тисяч неоподатковуваних мінімумів доходів громадян або громадськими роботами на строк від ста п'ятдесяти до двохсот сорока годин, або обмеженням волі на строк до двох років, 3 позбавленням права 
обіймати певні посади чи займатися певною діяльністю на строк до трьох років.

Тобто, якщо зроблено акцент на умисному внесенні суб'єктом декларування завідомо недостовірних відомостей до декларації законодавець припускає, що таке внесення може бути і неумисним? Варто також відзначити, що 31 січня 2021 р. 1 прожитковий мінімум для працездатних осіб становить 2270 грн. для уточнення наведемо цифри (похибку), яка відрізняє від достовірних даних наведених у декларації від 1135000 грн. до 9080000 грн., або понад 9080000 грн.. Виникає питання чи справді декларант неумисно міг допуститися такої помилки?

Вважаємо, що у диспозиції статті 366-2 КК України недоцільно писати «умисно». А відповідальність за декларування недостовірної інформації варто посилити, щоб убезпечити українське суспільство від такого роду суспільно небезпечних діянь.

Доцільно було б ст. 366-2 «Декларування недостовірної інформації» КК України викласти в такій редакції:

«1. Внесення суб'єктом декларування завідомо недостовірних відомостей до декларації особи, уповноваженої на виконання функцій держави або місцевого самоврядування, передбаченої Законом України «Про запобігання корупції», якщо такі відомості відрізняються від достовірних на суму від 300 до 4000 прожиткових мінімумів для працездатних осіб, - карається обмеженням волі на строк до трьох років, або позбавленням волі на той самий строк.

2. Внесення суб'єктом декларування завідомо недостовірних відомостей до декларації особи, уповноваженої на виконання функцій держави або місцевого самоврядування, передбаченої Законом України «Про запобігання корупції», якщо такі відомості відрізняються від достовірних на суму понад 4000 прожиткових мінімумів для працездатних осіб, - карається позбавленням волі на строк до трьох років 3 позбавленням права обіймати певні посади чи займатися певною діяльністю на строк до чотирьох років».

Відповідно, ст. 366-3 «Неподання суб'єктом декларування декларації особи, уповноваженої на виконання функцій держави або місцевого самоврядування» КК України пропонуємо викласти в такій редакції:

«Умисне неподання суб'єктом декларування декларації особи, уповноваженої на виконання функцій держави або місцевого самоврядування, передбаченої Законом України «Про запобігання корупції», - 
карається позбавленням волі на строк до трьох років з позбавленням права обіймати певні посади чи займатися певною діяльністю на строк до чотирьох років».

Ч. 5 ст. 172-6 «Порушення вимог фінансового контролю» КУПАП викласти в такій редакції:

«Відповідальність за цією статтею за подання завідомо недостовірних відомостей у декларації особи, уповноваженої на виконання функцій держави або місцевого самоврядування, стосовно майна або іншого об'єкта декларування, що має вартість, настає у випадку, якщо такі відомості відрізняються від достовірних на суму від 100 до 300 прожиткових мінімумів для працездатних осіб».

Підсумовуючи викладене, доцільно наголосити на тому, що все ж таки позитивним є криміналізація декларування недостовірної інформації та неподання суб'єктом декларування декларації особи, уповноваженої на виконання функцій держави або місцевого самоврядування. Однак, якщо йде мова про кримінальну відповідальність, покарання за такого роду діяння мають бути жорстокими.

\section{Література:}

1. Конституція України: Закон України від 28.06.1996 p. № 254к/96-BP. URL: https://zakon.rada.gov.ua/laws/show/254\%D0\%BA/ 96-\%D0\%B2\%D1\%80\#Text

2. Рішенням Конституційного Суду України у справі за конституційним поданням 47 народних депутатів України щодо відповідності Конституції України (конституційності) окремих положень Закону України «Про запобігання корупції», Кримінального кодексу України від 27.10.2020 р. № 13-p/2020. URL: https://zakon.rada.gov.ua/ laws/show/v013p710-20\#Text

3. Окрема думка судді Конституційного Суду України Первомайського О.О. у справі за конституційним поданням 47 народних депутатів України щодо відповідності Конституції України (конституційності) окремих положень Закону України «Про запобігання корупції», Кримінального кодексу України. URL: https://zakon.rada.gov.ua/ laws/show/nd13d710-20\#Text

4. Про внесення змін до деяких законодавчих актів України щодо встановлення відповідальності за декларування недостовірної інформації та неподання суб'єктом декларування декларації особи, уповноваженої на виконання функцій держави або місцевого самоврядування: Закон України від 4.12.2020 p. № 1074-IX. URL: https://zakon.rada.gov.ua/ laws/show/1074-20\#Text 
5. Кримінальний кодекс України: Закон України від 5.04.2001 p. № 2341-III. URL: https://zakon.rada.gov.ua/laws/show/2341-14\#Text

6. Кодекс України про адміністративні правопорушення: Закон України від 7.12.1984 р. № 8073-X. URL: https://zakon.rada.gov.ua/ laws/show/80731-10\#Text

DOI https://doi.org/10.30525/978-9934-26-040-7-52

\title{
ПРОТИДІЯ НАСИЛЬНИЦЬКИМ СТАТЕВИМ ЗЛОЧИНАМ В УКРАЇНІ
}

\author{
Юрченко Р. А. \\ acnipaнm \\ Донецького юридичного інституту \\ Міністерства внутрішніх справ України \\ м. Маріуполь, Донецька область, Україна
}

Не можна заперечувати того, що насильницькі злочини (насильницька злочинність) суттєво впливають на стан розвитку людського капіталу будь-якої країни, а життя, здоров'я, воля, честь, гідність та недоторканість особи $\epsilon$ найвищими цінностями, які захищаються державою. Відповідно до звіту Всесвітньої організації охорони здоров'я (далі - ВОО3), у 133-х опитаних країнах половина з них (51\%) мала постійні національні плани зі зменшення різних видів насильства, які впливають на окремі категорії осіб і суспільство в цілому. Вони варіюються від групового і молодіжного насильства, насильства з боку інтимного партнера, сексуального насильства і жорстокого поводження з людьми похилого віку [1].

Так, зокрема, із результатів дослідження ВООЗ, виділимо наступні статистичні дані: 1) від $15 \%$ жінок в Японії до 70\% жінок в Ефіопії і Перу повідомили про фізичне i/або сексуальне насильство з боку інтимного партнера; 2) від $0,3 \%$ до $11,5 \%$ жінок повідомили про сексуальне насильство в віці після досягнення 15 років з боку особи, яка не є партнером; 3) за повідомленнями багатьох жінок, їх перший сексуальний досвід був насильницьким: $17 \%$ жінок в сільських районах Танзанії, $24 \%$ в сільських районах Перу і $30 \%$ в сільських районах Бангладеш повідомили про це [2]. Наведені нами дані 